TWENTIETH-CENTURY LITERARY THEORY 
Also by K. M. Newton

THEORY INTO PRACTICE 


\section{Twentieth-Century Literary Theory}

A Reader

Second Edition

Edited by

K. M. Newton

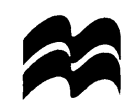

Macmillan Education 
TWENTIETH-CENTURY LITERARY THEORY

Introduction, editorial matter and selection (C) 1997 K. M. Newton

Softcover reprint of the hardcover 2nd edition 1997 978-0-333-67741-4

All rights reserved. No part of this book may be used or reproduced in any manner whatsoever without written permission except in the case of brief quotations embodied in critical articles or reviews.

For information, address:

St. Martin's Press, Scholarly and Reference Division, 175 Fifth Avenue, New York, N.Y. 10010

First edition 1988

Second edition 1997

This book is printed on paper suitable for recycling and made from fully managed and sustained forest sources.

ISBN 978-0-333-67742-1 ISBN 978-1-349-25934-2 (eBook)

DOI 10.1007/978-1-349-25934-2

Library of Congress Cataloging-in-Publication Data

Twentieth century literary theory : a reader / edited by K.M. Newton.

-2 nd ed.

p. $\mathrm{cm}$.

Includes bibliographical references and index.

ISBN 978-0-312-17588-7 (cloth : alk. paper). — ISBN 978-0-312-17589-4

(pbk. : alk. paper)

1. Criticism-History-20th century. I. Newton, K. M.

PN94.T87 1998

$801^{\prime} .95 ' 0904-\mathrm{dc} 21$ 


\section{CONTENTS}

Acknowledgements $\quad$ ix

Introduction $\quad$ xiii

I RUSSIAN FORMALISM AND PRAGUE STRUCTURALISM 1

1 Victor Shklovsky: 'Art as Technique' 3

2 Roman Jakobson: 'The Dominant' 6

3 P. N. Medvedev/M. Bakhtin: 'The Object, Tasks and Methods of Literary History' 10

4 Jan Mukařovský: 'Aesthetic Function, Norm and Value as Social Facts'

II THE NEW CRITICISM AND LEAVISIAN CRITICISM

$5 \quad$ I. A. Richards: 'Poetry and Beliefs' 22

6 Cleanth Brooks: 'The Formalist Critic' 26

7 Kenneth Burke: 'Formalist Criticism: Its Principles and Limits' $\quad 30$

8 John M. Ellis: 'The Relevant Context of a Literary Text' 34

9 F. R. Leavis: 'Literary Criticism and Philosophy' 37

10 John Casey: 'Object, Feeling and Judgement: F. R. Leavis'

III HERMENEUTICS 45

11 Hans-Georg Gadamer: 'Language as Determination of the Hermeneutic Object'

12 E. D. Hirsch, Jr: 'Three Dimensions of Hermeneutics'

13 P. D. Juhl: 'The Appeal to the Text: What Are We Appealing to?'

14 Paul Ricoeur: 'The Conflict of Interpretations' 60

15 William V. Spanos: 'Breaking the Circle: Hermeneutics as Dis-closure' 
vi CONTENTS

IV LINGUISTIC CRITICISM 70

16 Roman Jakobson: 'Linguistics and Poetics' 71

17 Roger Fowler: 'Literature as Discourse' 77

V STRUCTURALISM AND SEMIOTICS 83

18 Tzvetan Todorov: 'Definition of Poetics' 86

19 Gérard Genette: 'Structuralism and Literary

20 Roland Barthes: 'Science versus Literature' 94

21 Jonathan Culler: 'Semiotics as a Theory of Reading' 98

22 Yury M. Lotman: 'The Content and Structure of the Concept of "Literature", 102

23 Morse Peckham: 'The Problem of Interpretation' 106

VI POST-STRUCTURALISM 112

24 Jacques Derrida: 'Structure, Sign and Play in the Discourse of the Human Sciences'

25 Roland Barthes: 'The Death of the Author'

26 Julia Kristeva: 'The System and the Speaking Subject'

27 Michel Foucault: 'Lecture: 7 January 1976'

28 Paul de Man: 'The Resistance to Theory'

VII PSYCHOANALYTIC CRITICISM

29 Norman N. Holland: 'Reading and Identity: A Psychoanalytic Revolution'

30 Harold Bloom: 'Poetry, Revisionism and Repression'

31 Shoshana Felman: 'The Madness of Interpretation: Literature and Psychoanalysis'

VIII MARXIST AND NEO-MARXIST CRITICISM

32 Christopher Caudwell: 'English Poets: The Decline of Capitalism'

33 Georg Lukács: 'Critical Realism and Socialist Realism'

34 Walter Benjamin: 'The Author as Producer'

35 Terry Eagleton: 'Towards a Science of the Text'

36 Rosalind Coward and John Ellis: 'S/Z' 
37 Fredric Jameson: 'On Interpretation: Literature as a Socially Symbolic Act'

IX RECEPTION THEORYAND READER-RESPONSE CRITICISM

38 Hans Robert Jauss: 'Literary History as a Challenge to Literary Theory'

39 Wolfgang Iser: 'Indeterminacy and the Reader's Response'

40 David Bleich: 'The Subjective Character of Critical Interpretation'

41 Stanley Fish: 'Interpreting the Variomum' 203

$\begin{array}{lll}X & \text { FEMINIST CRITICISM } & 210\end{array}$

42 Josephine Donovan: 'Beyond the Net: Feminist Criticism as Moral Criticism'

43 Elaine Showalter: 'Towards a Feminist Poetics'

44 Elizabeth A. Meese: 'Sexual Politics and Critical Judgment'

45 Hélène Cixous: 'Conversations'

XI CULTURAL MATERIALISM AND NEW HISTORICISM

46 Raymond Williams: 'Dominant, Residual and Emergent'

47 Louis A. Montrose: 'Professing the Renaissance: The Poetics and Politics of Culture'

48 Alan Sinfield: 'Reading Dissidence'

XII NEW PRAGMATISM

49 Steven Knapp and Walter Benn Michaels:

50 Stanley Fish: 'Consequences' 260

$\begin{array}{lll}\text { XIII POSTMODERNISM } & 266\end{array}$

51 Fredric Jameson: 'Postmodernism, or The Cultural Logic of Late Capitalism'

52 Linda Hutcheon: 'Theorizing the Postmodern' 
viii CONTENTS

XIV POST-COLONIAL CRITICISM 283

53 Edward W. Said: 'Overlapping Territories, Intertwined Histories' 284

54 Homi K. Bhabha: 'The Other Question: The Stereotype and Colonial Discourse' 293

$\begin{array}{ll}\text { Index } & 302\end{array}$ 


\section{ACKNOWLEDGEMENTS}

The editor and publishers wish to thank the following for permission to use copyright material: Roland Barthes, material from 'Death of the Author' in Image/Music/Text, trs. Stephen Heath (1977). English translation copyright $\odot 1977$ by Stephen Heath, by permission of Collins Publishers and Hill and Wang, a division of Farrar, Straus \& Giroux, Inc; and 'Science versus Literature', The Times Literary Supplement, 28 September 1967. Copyright (C) Times Supplements Ltd, 1967, by permission of Times Newspapers Ltd; Walter Benjamin, material from Understanding Brecht (1973), by permission of Verso/NLB; Homi K. Bhabha, material from 'The Other Question', Screen, 24:6 (1983), 18-36, by permission of Screen; David Bleich, material from 'The Subjective Character of Critical Interpretation', College English, 36 (1975), by permission of the National Council of Teachers of English and the author; Harold Bloom, material from Poetry and Repression (1976), by permission of Yale University Press; Cleanth Brooks, material from 'The Formalist Critic', Kenyon Review, 13 (1951), by permission of Kenyon Review and the author; Kenneth Burke, material from Language as Symbolic Action (1973), by permission of University of California Press; John Casey, material from The Language of Criticism (1960), Methuen \& Co, by permission of Routledge; Christopher Caudwell, material from Illusion and Reality (1946), by permission of Lawrence and Wishart Ltd; Hélène Cixous, material from Writing Differences: Readings from the Seminar of Hélène Cixous, ed. Susan Sellers, Open University Press (1988), by permission of Susan Sellers; Rosalind Coward and John Ellis, material from Language and Materialism (1977) Routledge and Kegan Paul; by permission of Routledge; Jonathan Culler, material from 'Semiotics as a Theory of Reading' in In Pursuit of Signs: Semiotics, Literature, Deconstruction (1981). Copyright $(\odot 1981$ by Jonathan Culler, by permission of Routledge and Cornell University Press; Paul de Man, material from 'The Resistance to Theory', Yale French Studies, 63 (1982), by permission of the editor; Jacques Derrida, material from The Structuralist Controversy (1972), by permission of Johns Hopkins University Press; Josephine Donavan, material from 'Beyond the Net: Feminist Criticism as a Moral Criticism', Denver Quarterly, 17 (1983), by permission of the editor; Terry Eagleton, material from Criticism and Ideology (1976), by permission of Verso/NLB; John M. Ellis, material from The Theory of Literary Criticism (1974), by permission of the 
University of California Press; Shoshana Felman, material from 'Turning the Screw of Interpretation', Yale French Studies, 55/56 (1977), by permission of the editor and author; Stanley Fish, material from Doing What Comes Naturally: Change, Rhetoric and the Practice of Theory in Literary and Legal Studies. Copyright (C) 1989 Duke University Press, by permission of Duke University Press; and from 'Interpreting the Variomum', Critical Inquiry (1976), by permission of University of Chicago Press; Michel Foucault, material from Power/Knowledge: Selected Interviews and Other Writings, ed. Colin Gordon. Text copyright (C) 1972, 1975, 1976, 1977 by Michel Foucault. This collection copyright $@ 1980$ by The Harvester Press, by permission of Prentice-Hall and Pantheon Books, a division of Random House, Inc; Roger Fowler, material from 'Literature as Discourse' in Literature as Social Discourse (1981), by permission of B.T. Batsford Ltd; Gérard Genette, material from 'Structuralism and Literary Criticism' in Figures of Literary Discourse (1982). Copyright (C) 1982 by Columbia University Press, by permission of Blackwell Publishers and Columbia University Press; E. D. Hirsch, Jr, material from 'Three Dimensions of Hermeneutics', New Literary History, 3 (1971-2), by permission of Johns Hopkins University Press; Norman N. Holland, material from 'Reading and Identity: A Psychoanalytic Revolution', Academy Forum (The American Academy of Psychoanalysis), 23 (1979), by permission of the author; Linda Hutcheon, material from 'Theorizing the Postmodern' in A Poetics of Postmodernism (1988), by permission of Routledge; Wolfgang Iser, material from Aspects of Narrative, ed. J. H. Miller (1971). Copyright (C) 1971 by Columbia University Press, by permission of Columbia University Press; Roman Jakobson, material from Readings in Russian Poetics, ed. L. Matejka and K. Pomorska (1978), by permission of University of Michigan; and Style in Language, ed. Thomas Sebeok (1960), by permission of MIT Press; Fredric Jameson, material from The Political Unconscious: Narrative as a Socially Symbolic Act (1981) Methuen \& Co. Copyright (C) 1981 by Cornell University Press, by permission of Cornell University Press and Routledge; and from 'Postmodernism, or The Cultural Logic of Late Capitalism', New Left Review, 146, July-August (1984), by permission of New Left Review; Hans Robert Jauss, material from Toward an Aesthetic of Reception (1982), The Harvester Press, by permission of Prentice-Hall and University of Minnesota Press; P. D. Juhl, material from Interpretation (1980), by permission of Princeton University Press; Steven Knapp and Walter Benn Michaels, material from 'Against Theory', Critical Inquiry, 8 (1982), by permission of The University of Chicago Press; Julia Kristeva, material from 'The System and the Speaking Subject', The Times Literary Supplement, 12 October 1973. Copyright (C) Times 
Supplements Ltd, 1973, by permission of TimesNewspapers Ltd; F. R. Leavis, material from The Common Pursuit (1962), Chatto \& Windus, by permission of Random House UK Ltd; Georg Lukács, material from The Meaning of Contemporary Realism (1963), by permission of The Merlin Press Ltd and Humanities Press International, Inc; P. N. Medvedev/M. M. Bakhtin, material from The Formal Method in Literary Scholarship (1978), by permission of Johns Hopkins University Press; Elizabeth A. Meese, material from 'Sexual Politics and Critical Judgment' in After Strange Texts: The Role of Theory in the Study of Literature, ed. Gregory S. Jay and David L. Miller. Copyright (C) 1985 The University of Alabama Press, by permission of The University of Alabama Press; Jan Mukarovský, material from Aesthetic Function, Norm, and Value as Social Facts (1979), by permission of University of Michigan; Morse Peckham, material from 'The Problem of Interpretation', College Literature, 6 (1979), by permission of West Chester University and the author; I. A. Richards, material from Poetries and Sciences (1970), Routledge \& Kegan Paul, by permission of Routledge; Paul Ricoeur, material from Freud and Philosophy, trs. Denis Savage (1970), by permission of Yale University Press; Edward W. Said, material from Culture and Imperialism (1993), Chatto \& Windus. Copyright (C) 1993 by Edward Said, by permission of Random House UK Ltd and The Wylie Agency, Inc. on behalf of the author; Victor Shklovsky, material from Russian Formalist Criticism (1965), ed. Lee Y. Lemon and Marion J. Reis, by permission of University of Nebraska Press; Elaine Showalter, material from Women Writing and Women Writing About Women, ed. Mary Jacobus (1979), by permission of Croom Helm and Barnes and Noble Books; Alan Sinfield, material from Faultlines: Cultural Materialism and the Politics of Dissident Reading (1992), Clarendon Press. Copyright (C) 1992 Alan Sinfield and The Regents of the University of California, by permission of Oxford University Press and University of California Press; William V. Spanos, material from 'Breaking the Circle: Hermeneutics as Disclosure', boundary 2, 5 (1977), by permission of the author; Tzvetan Todorov, material from Introduction to Poetics (1981), The Harvester Press, by permission of Prentice-Hall and University of Minnesota Press; H. Aram Veeser, material from The New Historicism (1989) by permission of Routledge, New York and London; Raymond Williams, material from Marxism and Literature (1977). Copyright ( 1977 by Oxford University Press, by permission of Oxford University Press.

Every effort has been made to trace the copyright holders but if any have been inadvertently overlooked the publishers will be pleased to make the necessary arrangement at the first opportunity. 


\section{INTRODUCTION}

No one concerned with developments in literary criticism over the past thirty years or so can ignore the fact that there has been a great revival of interest in questions of theory. Probably the main reason for this has been the impact on literary criticism in the 1960s and 1970 s of structuralism and post-structuralism, which presented a serious challenge both to conventional historically based criticism and to the Anglo-American New Critical tradition. Theoretical issues, apparently dormant in the English-speaking world at least for several decades, were revitalised and new forms of critical approach in which theory and practice were intermingled, such as deconstruction, reception theory, reader-response criticism, feminism, psychoanalytic criticism, various types of Marxist and Marxist-influenced criticism, emerged. One still hears talk of a 'crisis' in literary studies having been created as a consequence of this, though such a crisis is taking a long time to come to a head. However, one clear effect of this was to break down any critical consensus and replace it with warring factions. More recently perhaps, these factions have learned to tolerate each other. But though what have been called the 'theory wars' may be over, theory itself remains central to modern critical practice.

Clearly this situation presents those who are beginning to study literature with serious difficulties since current criticism demands some knowledge of recent theoretical developments. Various literary theory collections and overviews of theory have therefore been published in an attempt to make theoretical issues more accessible to a general literary audience. This book continues in that tradition. Unlike most other theory collections, however, it covers more than just theory since structuralism. It also includes a good deal of material written before 1960 though the greatest part of the book covers later theory. In my view some knowledge of earlier theory is necessary in order to understand later developments. Also most other collections tend to reprint complete essays or articles. This collection adopts a different approach in that it edits the texts selected. This has two major advantages, I believe. Complete essays are difficult for those beginning the study of literary theory to assimilate. In my edited versions I have tried to preserve the structure of the argument of each text, albeit in an abbreviated form, and to present it as sharply and coherently as 


\section{xiv INTRODUCTION}

possible. My aim has been to reprint sufficient material to allow the reader to grasp a particular argument in order either to be persuaded by it or to think of grounds for questioning it. The other major advantage is that this allows me to include a much wider range of material - 54 selections - within one volume of not inordinate length. Of course, I hope that users of this volume will find certain of the selections of sufficient interest that they will take the trouble to read the complete essay, article, chapter or book from which the selections are drawn.

Theory is an area of constant debate and confrontation and, to have an adequate understanding of it, it is necessary to have knowledge not merely of the arguments central to one or two particular standpoints but also of alternative positions explicitly or implicitly in conflict with them. It is also not enough to represent the major theories with only one example for there is conflict and debate not only between different theories but within them. Thus as well as representing a considerable range of theoretical positions, this book tries to show different aspects of or emphases within particular theories. Furthermore, I have tried to strike a balance between authors or particular texts that must be included in any representative collection of twentiethcentury literary theory, and work which will be less familiar and not easily available to a general literary audience but which is arguably equally important and interesting. Having some knowledge of the wider context of twentieth-century theory is at the very least a considerable help and in some cases a necessity in understanding current theory. I have tried not only to provide representative examples of particular theoretical perspectives but also to choose texts which highlight the debate between perspectives and which show some of the differences within them.

It may be objected that a book such as this, which is primarily designed to introduce the range of twentieth-century theory to students of literature in higher education and to a nonspecialist literary readership, could do more harm than good. Why does one need to burden the mind of students or readers of literature in general with theoretical questions? Can it not be objected that theory merely confuses such readers and has little positive effect on reading? Indeed it has been argued that only mature critics should concern themselves with the theoretical implications of their activity and that readers at a less advanced stage should not be exposed to theory. ${ }^{2}$ These objections need to be answered. 
The first point to make is that theory or critical principles that have some theoretical base underlie any form of reading, even the most naive, of a literary text. To be unconscious of or uninterested in theory does not mean that it is not present. With virtually all forms of non-literary discourse certain norms and constraints must govern how they are read if such discourses are to serve the interests and purposes that direct our reading. Thus though theoretical questions may be raised in relation to such discourses, theory must take second place to these interests and purposes. This is the case whether one is reading a cooking recipe, a newspaper article, a work of history or philosophy, or a scientific paper. But with literary discourse, there are no practical or logical necessities external to the discourse that determine how it must be read. Theory is therefore always implied in reading literary discourse, since whatever norms and constraints that govern how literary texts are read cannot be seen as an integral part of the discourse itself but are chosen, consciously or unconsciously, from among various possibilities by the reader.

In discussions of different forms of discourse, terms such as 'historical' or 'philosophical' or 'scientific' suggest a range of attributes or characteristics associated with the particular discourse, but the term 'literary' - despite numerous efforts at definition which claim that all texts that have been categorised as 'literary' have at least one common attribute - is empty. It does not refer to qualities that texts have in common but to what appears to be a human need to have a body of texts that exists beyond the pragmatic boundaries within which our reading of other forms of discourse must take place. There is no practical necessity or intrinsic constraint that can stop one using a text that has been categorised as 'literary' for any purpose whatsoever. The category 'literature', therefore, in the narrower, evaluative sense refers to certain of the texts that have been placed in the category of the non-pragmatic which readers and critics over several generations have judged to be particularly effective in serving their various interests.

It follows from what I have said that there could be as many theories of literature as there are readers. Obviously this is not the case. Indeed literary critical discourse exhibits a high degree of order and coherence, and it is perhaps only recently that this has been partially undermined, and many would lay the blame for this on the current literary critical context which has appeared to encourage a proliferation of theories. But even in the present situation there is no sign of complete relativism. Those who have 
uttered warnings of 'chaos' or 'anarchy' are employing rhetoric designed either to publicise their dislike of changes that have taken place within the literary community or to destabilise literary study for certain political purposes. A more interesting consideration is why there is so much order within literary study when literary discourse does not demand that there be any.

Since there are no pragmatic considerations that demand that certain norms and constraints must govern our reading of literary texts, the norms and constraints that do in fact govern our reading of them must have been chosen by us, even if we may not be aware of having made a choice. The reason, then, that literary criticism is comparatively ordered when there would appear to be no intrinsic need for it to be so is that most readers make the same kind of choice from the various options which they perceive to be available. Why so many different theoretical approaches to literature should have emerged in the twentieth century and why readers choose to support one rather than another are interesting questions. This is not the place to try to answer these questions in detail but clearly literary theory cannot be seen in isolation from the political and ideological conflicts which have been such a prominent feature of the twentieth century. Choices about reading, especially in relation to texts which exist beyond the pragmatic limits which govern our reading of other forms of discourse, cannot be ideologically neutral, and the reader may care to bear that in mind in reading the work of the various theorists included in this book.

Before twentieth-century developments in literary criticism the great majority of readers chose to relate literary texts to their historical context and to the intentions of their authors, and this approach still commands great support. But many twentiethcentury readers, in contrast, have chosen to pay little or no attention to historical context or authorial intention and allow modern modes of thought, such as psychoanalytic or feminist theory, to govern how they read literary texts. Such readers would argue that the most important consideration in liter-ary study is the text's relation to the concerns of a modern audience. There is also no limit to the number of interests that readers can choose to bring to bear on their reading of literary texts, the most common being aesthetic, historical, linguistic, sociological, biographical, philosophical, psychological, political or combinations of these.

It is important to stress, however, that one cannot do anything other than make a choice. Though there are no intrinsic norms and constraints that determine how we must read literary texts, 
as soon as we begin to read the text norms and constraints of some sort will come into operation since the very activity of reading cannot take place without them. It is inevitable that readers will make the same kind of choices so that one finds readers and critics forming into groups or, as Stanley Fish calls them, 'interpretive communities'. It is conceivable that an individual may develop an entirely idiosyncratic way of reading literary texts that does not conform to any community of readers that exists or has existed. Markers of certain student essays might find this idea persuasive. But, of course, it is inevitable that the vast majority of readers will accept the norms and constraints that govern the theories which are dominant in the culture at any particular time.

One of the most important arguments in favour of literary theory, therefore, is that since the norms and constraints are not intrinsic but are chosen for particular reasons, there is no justification for ignoring their existence as there might be in reading non-literary forms of discourse, even if this may result, as René Wellek has warned, ${ }^{3}$ in the minds of young students being unsettled. It would be bad faith to conceal the fact, even from young students, that no norms or constraints are integral to literary discourse and therefore privileged. Certain norms will, of course, be dominant and there may be justification for stressing their advantages and the dangers of discarding them but there can be no justification for claiming that these norms are intrinsic to the very existence of literary discourse.

An obvious implication of this is that once one knows that the norms and constraints that govern one's reading of literary texts have been chosen, then one may choose to change them. Though some may see such a possibility as a recipe for total relativism, the fact that any change cannot lead to norms being discarded altogether but only to the adoption of a different set of norms suggests that such fears are groundless. Indeed, it may have a positive benefit in that certain readers who have been operating with norms which are alien to their temperament or ideology or world-view may be able to choose a set of norms that they find much more congenial. This book thus has a double purpose: to make readers more aware of the norms and constraints which govern their existing critical approach and to be able to defend it against alternative approaches, and by comparing their present set of norms and interpretative strategies against alternatives to be in a position to adopt a different approach should they find one that is more persuasive. 


\section{XViii INTRODUCTION}

It would be inaccurate, however, to assert that the current situation of a 'proliferation of theories' has had no fundamental impact on literary criticism. One of the drawbacks of Stanley Fish's notion of 'interpretive communities' is that it implies that once readers of literary texts have chosen, consciously or not, their community there is little point in arguing with those who belong to different communities since it is not as if one community is right and all the others wrong. The very word 'community' suggests that one is part of a self-supporting group and that one need bother little with other communities. Yet one cannot but be struck by the constant debate and controversy that takes place in literary studies. Readers of literary texts do not seem content to adopt 'a live and let live' philosophy. This suggests that the 'communities' analogy needs to be modified.

The reason that there is so much controversy and debate in literary studies, I would argue, is that critics and readers feel they belong to a single community, even though they may have made quite different choices as to how they read literary texts. The very fact that they have had to make such a choice links them together with other readers and interpreters of texts. But since they could have chosen differently this will inevitably create the need to justify the choice they have made and encourage the desire to persuade others both that this choice is the right one and that other choices are mistaken. Literary criticism is in consequence an area of continual debate. Even though it is impossible for this debate ever to be resolved finally, the attempt to justify the position one has chosen and to defend it with rational argument against alternative positions is necessary if literary study is to remain vital. Controversy and debate need not be seen, therefore, as signs of crisis or destabilisation but as signs of health and vigour. Ultimately literary criticism is about politics and power, and a sign of crisis is more likely to be a situation in which debate and rational argument are stifled than one in which they are conducted vigorously.

Perhaps the analogy, therefore, that best describes the current situation of literary criticism is not that it is made up of a number of separate 'communities' but, rather, that it is like a parliament. Before the recent explosion in literary theory, that parliament in the English-speaking world resembled one in which two parties dominated and smaller parties were confined to an insignificant role. There was thus relative stability and order with perhaps one party dominating for a period and then the other, but both parties remained at all times sufficiently 
large not to feel threatened. Debate thus tended to follow predictable lines and there was, except among specialists, relatively little general interest in theoretical questions. These two parties were historical criticism which emphasised such matters as the text in relation to its time, what the author intended, generic considerations, and the New Critical tradition with its anti-intentionalist bias and its emphasis on the text as a self-contained structure.

What has happened to the 'parliament' more recently is that this two-party dominance has been threatened because numerous small parties have entered the parliament, depriving any single party of an overall majority. Most of these parties believe that they have a chance of achieving power and endeavour to persuade those who belong to other parties to join them. There is the likelihood of coalitions and realignments. Debate has become more urgent and acrimonious and theoretical questions have again become central. Literary criticism is thus revealed as a struggle for power among parties which are in a position to use only rational argument and rhetoric as a means of persuading sufficient numbers to support them in order to achieve a majority. The debate also has significance for society in general in that it raises questions that have implications beyond the purely literary sphere. In this anthology of theory, readers can follow the debate with a view to deciding eventually where to cast their votes or they may decide that another new party is needed. But in any case anyone who retains an interest in literature has no option but to vote.

\section{NOTES}

1. See Antony Easthope, Literary Into Cultural Studies (London, 1991), p. 11 .

2. See René Wellek, 'Respect for Tradition', The Times Literary Supplement, 10 December 1982, p. 1356.

3. Ibid. 